\title{
Reproductive traits and population structure of Astyanax aeneus (Characiformes: Characidae) from a subtropical river in Mexico
}

\author{
Patricia Trujillo-Jiménez ${ }^{1}$, Jacinto Elias Sedeño-Díaz ${ }^{2}$, Julio A. Camargo ${ }^{3}$ \\ \& Eugenia López-López ${ }^{4 *}$ \\ 1. Centro de Investigaciones Biológicas, Universidad Autónoma del Estado de Morelos, Av. Universidad 1001, Col. \\ Chamilpa, C.P. 62209, Cuernavaca, Morelos, Mexico; trujill@uaem.mx \\ 2. Programa Ambiental, Av. Wilfrido Massieu s/n. Esq. Av. Luis Enrique Erro. Col. Zacatenco, Mexico, D.F., Mexico; \\ jsedeno@ipn.mx \\ 3. Departamento de Ecología, Facultad de Biología, Universidad de Alcalá, Ctra. Madrid-Barcelona km. 33,6 28871 \\ Alcalá de Henares, Madrid, Spain; julio.camargo@uah.es \\ 4*. Laboratorio de Ictiología y Limnología, Escuela Nacional de Ciencias Biológicas, IPN, Prol. de Carpio y Plan de \\ Ayala s/n, Col. Sto. Tomás, Mexico, D.F., 11340 Mexico; eulopez@ipn.mx \\ * Corresponding author
}

Received 14-V-2012. Corrected 10-IX-2012. Accepted 03-X-2012.

\begin{abstract}
Rasgos reproductivos y estructura de la población de Astyanax aeneus (Characiformes: Characidae) de un río subtropical en México. Champotón River is an unknown area within the Mesoamerican hotspot in Southestern México. Reproductive traits and population structure of Astyanax aeneus were analyzed along an environmental gradient of the upper, middle and lower sections of the river, where diverse environmental factors were recorded. For this, nets were cast for $1 \mathrm{~h}$ at each site and A. aeneus were collected from all sections with sweep nets ( 5 and $10 \mathrm{~m}$ long by $5 \mathrm{~m}$ deep, $0.03 \mathrm{~m}$ mesh size) and a casting net $(0.05 \mathrm{~m}$ mesh size). At each study site and campaign, a total of 80 specimens (in average) were collected and were fixed in $10 \%$ formaldehyde for further analysis. Population structure by size was analyzed for each study site, based on the relative frequencies by standard length classes. The length-weight relationship was determined, and the identification of gonadal developmental stages, reproductive period, size at first sexual maturity, relative fecundity, sex ratio and somatic indexes (gonadosomatic, hepatosomatic and Fulton's condition factor) were also assessed. Seven size classes were found in the upper and middle sections, and nine downstream, with seasonal and spatial pattern in size-class frequency distribution. Size at first maturity was $45.7 \mathrm{~mm}$ for females and $40.8 \mathrm{~mm}$ for males. The maximum relative fecundity was recorded at the downstream site and was positively correlated with body weight and standard length. Sex ratio (1.8:1 males: females) differed significantly from expected values (1:1). Gonadosomatic index scores indicated that the reproductive period of this species in the Champotón River was from April to July, during the warm and wet season. Hepatosomatic index was negatively correlated with the Gonadosomatic index, evidencing transfer of energy from the liver towards gamete production. This strategy enabled $A$. aeneus to maintain robustness during the study period with tiny changes in condition factor. $A$. aeneus in the Champotón River, as opposed to South American river congeneric species of similar size, shows early sexual maturity, a short reproductive period with high gonadosomatic index values, and high fecundity, a trade-off for the short reproductive period. Spatio-temporal segregation was evident: breeders congregate downstream, while juveniles prefer the upper reaches. This pattern allows $A$. aenus to be successful in a river with high frequency of hurricanes. Rev. Biol. Trop. 61 (2): 769-786. Epub 2013 June 01.
\end{abstract}

Key words: Astyanax aeneus, fish life history, first maturity, absolute fecundity, trade-off, hurricanes, environmental gradient. 
Organisms use various strategies in order to achieve a favorable interaction with the environment in terms of energy, fitting life-history stages that require high energy cost investment with stages of higher resource availability. A further strategy involves acquiring resources when they are available and abundant in order to accumulate reserves for use in periods of high energy demand (Stearns 1994). In wild animals, cycles of adipose tissue degradation and accumulation lead to the existence of different energetic states (favorable, stable and deficient) (Wunder 1992). These states are influenced by exogenous factors (climatic variations, food availability, competition and predation among others) as well as endogenous agents, particularly reproduction, an event to which many of the available resources are allocated. Reproduction is related to lifehistory theory, where continuous trade-offs occur between the ontogenetic process and reproductive traits affected by the environment (Stearns 1994).

To determine the impact of ontogeny and environment on reproductive traits, evaluation has been made of the physiological condition of animals, which is affected by factors such as nutritional condition, health status, and physiological deterioration (Ryan \& Rand 1993). These factors result from the interaction of endogenous elements such as metabolic rate, age and sex with exogenous elements such as food availability, climatic conditions and season of the year (Jones et al. 1999).

The energy costs of reproduction have been an essential part of almost all life-history studies and are always discussed in terms of resource allocation (Stearns 1994, Mazzoni \& Iglesias-Ríos 2007). Likewise, the reproductive effort involves the allocation of energy, among others. Kinnison et al. (2001) stated there are four major life-history traits (migratory behavior, reproductive period, fecundity, and egg size) which generate trade-offs among themselves in the establishment of any reproductive strategy. Stearns (1994) reports the existence of trade-offs at the phenotypical and genotypical levels, and at an intermediate level between these two (the intermediate structure). The intermediate structure may regulate correlations of gene expression through two compromises: age $v s$ size at sexual maturity and reproductive investment $v s$ survival.

Asymptotic length and length at first maturity are covarying life-history parameters that depend on individual growth rates, which are in turn affected by habitat conditions. Therefore, the evolution of these life-history parameters is adjusted in response to environmental conditions, i.e. the theoretical maximum length attained by individuals of different species or populations may vary depending on their habitat, so that length at first maturity is also modified. Length at first maturity, duration of the maturation cycle, and type of spawning are environmentally-shaped reproductive traits determining population survival (Lourenço et al. 2008).

Most studies comparing life histories in different types of habitat or in different species have considered relatively broad spatio-temporal scales (Magalhâes et al. 2003). However, few studies have focused on population variation at a small spatial scale, which is important in order to understand how fish populations persist under stress induced by environmental variability. To face local variability in habitat conditions, fish may display different patterns of energy allocation among survival, growth and reproduction (Gertum et al. 2008).

An interesting aspect of fish biology is the variety of reproductive strategies used by different fish groups. Knowledge of the reproductive biology of a species is essential to understand its population dynamics as well as to guide the management and conservation of organisms and their environment. The success of any species is determined ultimately by the reproductive capacity of its members in variable environments, and such a capacity keeps populations viable (Dala-Corte \& Azevedo 2010).

The general pattern of reproduction displayed by a species or a population characterizes its strategies, while reproductive tactics are traits that vary within this pattern and are 
evoked in response to environmental fluctuations. Length at first gonadal maturation, sex ratio, spawning periods and type of spawning, oocyte maturation, and fecundity are examples of variable traits in the reproductive strategy of each species (Gomiero et al. 2008).

The aim of this study was to examine spatio-temporal variation in the population structure and reproductive biology of Astyanax aeneus (Günther 1860) along a longitudinal gradient in the Champotón River, through analysis of the reproductive period and its potential correlations with abiotic and biotic variables as well as determination of reproductive cycle stages, sex ratio, size at first maturity and reproduction-related morphological indexes. This type of study has been proposed because, in addition to clearing up aspects related to the biology of a species, it provides valuable information on the potential effects of environmental changes on species reproduction and survival.

\section{MATERIALS AND METHODS}

Study area: The Southeastern Mexico has the most extensive and diverse aquatic ecosystems in Mexico, which are of great importance in terms of productivity and biodiversity. The Champotón River basin is classified as a priority hydrological region by the National Commission for the Knowledge and Use of Biodiversity; the river is within the so-called Mesoamerican hotspot (Myers et al. 2000).

The Champotón River $\left(19^{\circ} 24^{\prime} 10^{\prime \prime} \mathrm{N}\right.$ $90^{\circ} 46^{\prime} 15^{\prime \prime} \mathrm{W}$ and $19^{\circ} 16^{\prime} 47^{\prime \prime} \mathrm{N}-90^{\circ} 27^{\prime} 18^{\prime \prime}$ $\mathrm{W})$, the main surface stream in the Yucatán Peninsula, is located in the humid subtropics of Southeastern Mexico, and contains high amounts of karstic material. This coastal river is $55 \mathrm{~km}$ in length to its mouth; no tributaries add to its flow and its course can be divided into a freshwater portion with salinity up to 1.2 practical salinity units, and an estuary where salinity reaches 10 to 35 practical salinity units, except during the hurricane season when conditions may decrease salinity (López-López et al. 2009).
The climatic regime is hot subhumid with summer rain (June to September) and occasional winter precipitation as a result of the windy (Northerly) and hurricane seasons. The surrounding vegetation consists of mangrove swamps in the lower reaches and medium to low perennial rain forest in the rest of the basin. In 2007, the region was affected by several hurricanes (mostly from August to October), with a maximum precipitation of $295.8 \mathrm{~mm}$ and caused the river overflow.

Three study sites were selected in the freshwater portion of the river (Fig. 1): San Juan Carpizo (SJC) (19¹8'29" N - 90²8'40" $\mathrm{W})$ in the upper portion of the river $(51.6 \mathrm{~km}$ away from the river mouth), San Antonio del Río (SAR) $\left(19^{\circ} 19^{\prime} 33^{\prime \prime} \mathrm{N}\right.$ and 90³3'39” W) in the middle portion $(39 \mathrm{~km}$ away from the river mouth), and Ulumal (U) $\left(19^{\circ} 16 . ' 30^{\prime \prime} \mathrm{N}\right.$ - $90^{\circ} 37^{\prime} 25^{\prime \prime} \mathrm{W}$ ) in the middle portion named "downstream" (25km away from the river mouth). Five campaigns were conducted at the study sites that include the seasonal changes affecting the study area: Winter in January, Spring and dry season in April, Summer (rainy season) in July, and November 2007 the Fall (hurricane effects) and Winter (with post hurricane effects) February 2008.

Methods: Diverse environmental factors were recorded at each site using a Quanta multiparametric sonde: dissolved oxygen

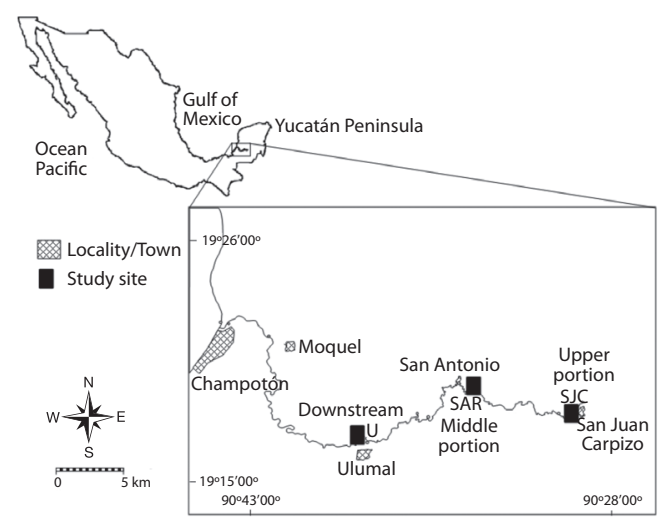

Fig. 1. Study area.

Fig. 1. Área de estudio. 
(DO mg/L), temperature $\left({ }^{\circ} \mathrm{C}\right), \mathrm{pH}$ and salinity (PSU). Biochemical oxygen demand $\left(\mathrm{BOD}_{5}\right.$ $\mathrm{mg} / \mathrm{L}$ ) was quantified according to American Public Health Association procedures (2005).

For habitat characterization the following variables were recorded: altitude above sea level (m), using an altimeter, maximum depth (m) using a depth sounder and maximum amplitude. The precipitation and air temperature values were obtained from the Mexican National Weather Service (Servicio Meteorológico Nacional 2008).

A. aeneus were collected between the $8 \mathrm{~h}$ and $16 \mathrm{~h}$ range, with sweep nets 5 and $10 \mathrm{~m}$ long by $5 \mathrm{~m}$ deep $(0.03 \mathrm{~m}$ mesh size $)$ and a $0.05 \mathrm{~m}$ mesh size casting net. Nets were cast for $1 \mathrm{hr}$ at each site covering about $100 \mathrm{~m}$, in order to provide a representative sample of fish fauna per site. All depths of the river were covered, and pools as well as riffles and areas with vegetation were considered. Each campaign collected an average of 80 specimens at each study site; all fish were fixed in $10 \%$ formaldehyde for further analysis.

We analyzed a total of 1286 specimens, all of them were measured (standard length=Ls in $\mathrm{mm}$ ) with a digital caliper model CD-8 and an Ohaus analytical balance Explorer $(0.0001 \mathrm{~g})$, total $(\mathrm{Wt})$, eviscerated weight (We), liver weight $(\mathrm{Wh})$ and gonad weight $(\mathrm{Wg})$ were measured.

Population structure was analyzed by size, based on the relative frequencies of standard length classes of each study site. Standard length varied from 13 to $95 \mathrm{~mm}$. Nine length classes were established according to the methodology proposed from Vitule et al. (2008), with closed intervals of $10 \mathrm{~mm}$ and each interval with a code: Class 1 (11-20mm); Class 2 (21-30mm) and so on until Class 9 (91$100 \mathrm{~mm})$. Significant differences were determined from the length classes frequencies with a Chi-square test $X^{2}(p<0.05)$.

The length-weight relationship for each sex was derived using the equation: $\mathrm{Wt}=\mathrm{aLs} \mathrm{s}^{\mathrm{b}}$. Significant differences were determined between coefficient $b$ of females and males. The Kruskal-Wallis test was used to confirm the existence of significant differences with $p$ set at $\mathrm{p}=0.05$ (Samat et al. 2008).

The identification of gonadal developmental stages was made using the gonad characteristics: size, shape, color and oocytes color, following Vitule et al. (2007). The stages of gonadal maturation in females were classified according to the following criteria: immature $=$ undeveloped gonads consisting of a small filament of translucent color; maturation $1=$ intermediate size ovary with pale-white oocytes, small visible to naked eye; maturation $2=$ more developed ovary with yellow oocytes; ripe ovary=fully developed ovary filling ventral region of the abdominal cavity, with yellow oocytes; post spawning=ovary was very flaccid and little significant presence of ripe oocytes. The stages of gonadal maturation in males were classified according to the following criteria: immature $=$ undeveloped testis consisting of a small translucent filament; maturation $1=$ intermediate size testis with translucent white colour; maturation $2=$ large testis, opaque white colour; ripe testis = fully developed testis; post spawning $=$ flaccid testis.

The reproductive period was defined as the time at which the largest relative frequency of females and males with mature gonads or gonads in post-spawning were noted and maximum mean monthly GSI values were recorded.

To estimate the first sexual maturity $\left(\mathrm{L}_{50}\right)$ size of females and males, data were inserted in a logistical model as follows: $\mathrm{P}=1 /(1+\mathrm{e}-\mathrm{r}(\mathrm{Ls}-$ $\left.\mathrm{L}_{50}\right)$ ) according to the Environmental Protection Agency's probit method (Environmental Protection Agency 2011), where P is the proportion of mature individuals; Ls is the standard length for proportion $\mathrm{P}$; $\mathrm{r}$ is a constant; and $\mathrm{L}_{50}$ is the mean size at first sexual maturity, which was taken to be the size at which $50 \%$ of individuals were mature (Vazzoler 1996).

Relative fecundity (RF) was obtained by counting the number of oocytes absolute fecundity (AF) in 88 mature females and expressed in relation to body weight (Adebisi 1987). Pearson's correlation coefficient $(p<0.05)$ was used to find correlations between RF and biometric factors (Ls and W). Regression fitting 
was applied to the relationships RF $v s$ Ls and RF vs W. The sex ratio was determined as the proportion of females to males expressed as a percentage of the total sample. The chi-square $\mathrm{C}^{2}(\mathrm{p}<0.05)$ test was used to confirm a significant difference in sex ratio.

Gonadosomatic index (GSI), hepatosomatic index (HSI) and Fulton's condition factor $(\mathrm{K})$, were estimated in immature individuals, females and males using the following equations: $\mathrm{GSI}=(\mathrm{Wg} / \mathrm{We}) * 100$; $\mathrm{HSI}=(\mathrm{Wh} /$ $\mathrm{We})^{*} 100$ and $\mathrm{K}=\left(\mathrm{We} / \mathrm{Ls}^{3}\right)$. One-way analysis of variance (ANOVA) followed by Tukey's test $(p<0.0001)$ was used to compare differences in $\mathrm{K}$ values among immature individuals, females and males.

Correlations between GSI values and mean water temperature, precipitation and between HSI and $\mathrm{K}$ values were evaluated with Spearman's correlation using XLSTATPro 2010.2.03 software. A two-matrix discriminant analysis (DA) was used. One matrix included the physico-chemical parameters of water (dissolved oxygen, temperature), biochemical oxygen demand $\left(\mathrm{BOD}_{5}\right)$, and habitat characteristics (water depth, maximum width, altitude) as well as precipitation. The second matrix included the morphological indices (GSI, HSI, K), sex, standard length (Ls), size classes and gonadal stages. Data were all log $(x+1)$ transformed. Biological indexes, sex, Ls, size classes and gonadal stages were square root-transformed. The analysis was performed with XLSTAT-Pro 2010.2.03.

\section{RESULTS}

Rainfall records of the Mexican National Weather Service (Servicio Meteorológico Nacional 2008) showed that the annual mean precipitation in the area was $61.81 \mathrm{~mm}$ during the study period, with a minimum mean value of $0.57 \mathrm{~mm}$ in the dry season (March and May), and a maximum mean value of $161 \mathrm{~mm}$ in the hurricane season (August and October) (Fig. 2). Overflowing of the river took place in September and continued through November (amplitudes of the river, average

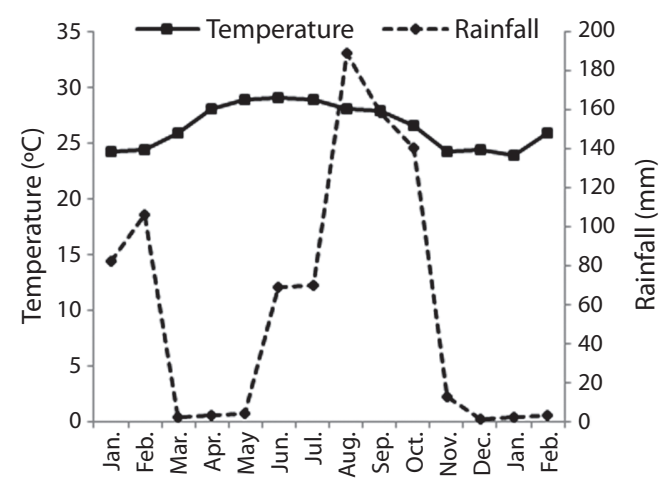

Fig. 2. Mean monthly values of temperature and precipitation in Champoton, Campeche, Mexico, according to the National Weather Service of Mexico (Servicio Meteorológico Nacional de México 2008).

Fig. 2. Valores medios mensuales de temperatura y precipitación en Champotón, Campeche, México, Servicio Meteorológico Nacional de México 2008.

$29 \mathrm{~m}$, minimum $15 \mathrm{~m}$ SJC, maximum $47 \mathrm{~m}$ in U) (Table 1). Mean air temperature fluctuated: the maximum values were recorded in June and July during the summer period (28.3 and $28.2^{\circ} \mathrm{C}$, respectively) and the minimum value in January $2008\left(22.8^{\circ} \mathrm{C}\right)$ (Fig. 2).

Maximum temperature values were recorded in April and July (28.7 and $29.7^{\circ} \mathrm{C}$, respectively) and the minimum in November $\left(24.3^{\circ} \mathrm{C}\right)$. DO levels were highest in January and November $(6.7 \mathrm{mg} / \mathrm{L}$ both months) and lowest in July and February $(5.7$ and $5.3 \mathrm{mg} / \mathrm{L}$ respectively), and $\mathrm{pH}$ values remained constant throughout the study period (range of 7.3 to 8). Salinity oscillated from 0.1 PSU in November at all study sites to 1.2 PSU in July at $\mathrm{U}_{\text {. }} \mathrm{BOD}_{5}$ attained minimum values in November and maximum values in April at all sites (Table 1).

Population structure by size: A spatial and seasonal pattern was noted in the size-class frequency distribution. The downstream site was the only one where all nine class sizes were detected, (Fig. 3 a, b and c); furthermore, classes 6 and 7 had the highest frequencies in April and July (Fig. 3c). At the upper and middle portion of the river only seven classes (1 to 7) were detected. Youngest organisms had 
TABLE 1

Mean values of physicochemical parameters in time and space of the Río Champotón. $\mathrm{U}=$ upper portion, $\mathrm{M}=$ middle portion, $\mathrm{D}=$ downstream. Values after \pm are standard deviation

\section{CUADRO 1}

Valores medio de los parámetros físco-químicos en el tiempo y espacio del Río Champotón. $\mathrm{U}=$ Parte alta, $\mathrm{M}=$ Parte media, $\mathrm{D}=$ río abajo. Los valores después del \pm son las desviaciones estándar

\begin{tabular}{|c|c|c|c|c|c|c|c|c|}
\hline & Study sites & $\begin{array}{c}\text { Temperature } \\
\left({ }^{\circ} \mathrm{C}\right)\end{array}$ & $\mathrm{O}_{2}(\mathrm{mg} / \mathrm{L})$ & $\mathrm{pH}$ & $\begin{array}{l}\text { Salinity } \\
\text { (PSU) }\end{array}$ & $\begin{array}{l}\mathrm{BOD}_{5} \\
(\mathrm{mg} / \mathrm{L})\end{array}$ & $\begin{array}{l}\text { Maximum } \\
\text { depth (m) }\end{array}$ & $\begin{array}{c}\text { Maximum } \\
\text { amplitude }(\mathrm{m})\end{array}$ \\
\hline \multirow[t]{4}{*}{ Jan } & $\mathrm{U}$ & 26 & 6 & 7 & 1 & 6 & 0.7 & 9 \\
\hline & M & 27 & 8 & 8 & 1 & 3 & 2 & 14 \\
\hline & $\mathrm{D}$ & 27 & 6 & 8 & 1 & 2 & 4 & 40 \\
\hline & Mean & $26.7 \pm 0.33$ & $6.7 \pm 0.67$ & $7.7 \pm 0.33$ & $1 \pm 0$ & $3.7 \pm 1.20$ & $2.2 \pm 0.96$ & $21 \pm 9.61$ \\
\hline \multirow[t]{4}{*}{ Apr } & $\mathrm{U}$ & 28 & 6 & 7 & 1 & 6 & 0.7 & 9 \\
\hline & M & 29 & 6 & 7 & 1 & 3 & 2 & 14 \\
\hline & $\mathrm{D}$ & 29 & 6 & 8 & 1 & 3 & 4 & 40 \\
\hline & Mean & $28.7 \pm 0.33$ & $6 \pm 0$ & $7.3 \pm 0.33$ & $1 \pm 0$ & $4 \pm 1.0$ & $2.2 \pm 0.96$ & $21 \pm 9.61$ \\
\hline \multirow[t]{4}{*}{ Jul } & $\mathrm{U}$ & 30 & 5 & 7 & 1 & 1 & 0.7 & 9 \\
\hline & M & 29 & 6 & 8 & 1 & 1 & 2 & 14 \\
\hline & $\mathrm{D}$ & 30 & 6 & 8 & 1 & 1 & 6 & 40 \\
\hline & Mean & $29.7 \pm 0.33$ & $5.7 \pm 0.33$ & $7.7 \pm 0.33$ & $1 \pm 0$ & $1 \pm 0$ & $2.9 \pm 1.59$ & $21 \pm 9.61$ \\
\hline \multirow[t]{4}{*}{ Nov } & $\mathrm{U}$ & 23 & 5 & 8 & 0.1 & 0.7 & 3 & 48 \\
\hline & M & 26 & 8 & 8 & 0.1 & 0.7 & 3 & 46 \\
\hline & $\mathrm{D}$ & 23.9 & 7 & 7.8 & 0.1 & 0.6 & 7 & 43 \\
\hline & Mean & $24.3 \pm 0.89$ & $6.7 \pm 0.88$ & $7.9 \pm 0.07$ & $0.1 \pm 9.8 \mathrm{E}^{-} 18$ & $0.7 \pm 0.03$ & $4.33 \pm 1.33$ & $45.66 \pm 1.45$ \\
\hline \multirow[t]{4}{*}{ Feb } & $\mathrm{U}$ & 26 & 4 & 8 & 1 & 3 & 1 & 15 \\
\hline & M & 27 & 6 & 8 & 1 & 1 & 3 & 25 \\
\hline & $\mathrm{D}$ & 27 & 6 & 8 & 1 & 0.9 & 7 & 40 \\
\hline & Mean & $26.7 \pm 0.33$ & $5.3 \pm 0.67$ & $8 \pm 0$ & $1 \pm 0$ & $1.6 \pm 0.68$ & $3.7 \pm 1.76$ & $26.7 \pm 7.26$ \\
\hline
\end{tabular}

a strong seasonal distributional pattern, class 1 was present only in April at the upper site, and in November at all study sites (Fig. 3b). Based on chi-square $\left(x^{2}\right)$ tests $(\mathrm{p}<0.05)$, significant differences were found between the size-class frequencies at the various study sites.

Length-weight relationship: The lengthweight relationship is shown in Fig. 4, along with its mathematical expression: parameter $b$ was 3.23 for females and 3.08 for males. The Kruskal-Wallis test found no significant differences between the sexes ( $p>0.05)$.

Reproduction: From the 1286 specimens collected, $818(63.60 \%)$ were males, $438(34.05 \%)$ were females and $30(2.33 \%)$ immature. Sex ratio was 1.87:1 (males:females), differing significantly from the expected $1: 1\left(x^{2}\right.$ $\mathrm{p}<0.05$ ). Males were significantly dominant during the whole period of study (Fig. 5).

Immature individuals were detected in the middle and downstream sites only in January and November (Figs. 6a and b). Females and males in maturity stage 1 were recorded during all sites and months studied, except for the downstream site in July, with the maximum abundance occurring in January at all three sites, and the minimum abundance in all study sites in April and July (Figs. 6a and b).

Females in maturity stage 2 were recorded in the middle and in the downstream sites in January and in April (respectively), and a peak was detected in the upper river site during 

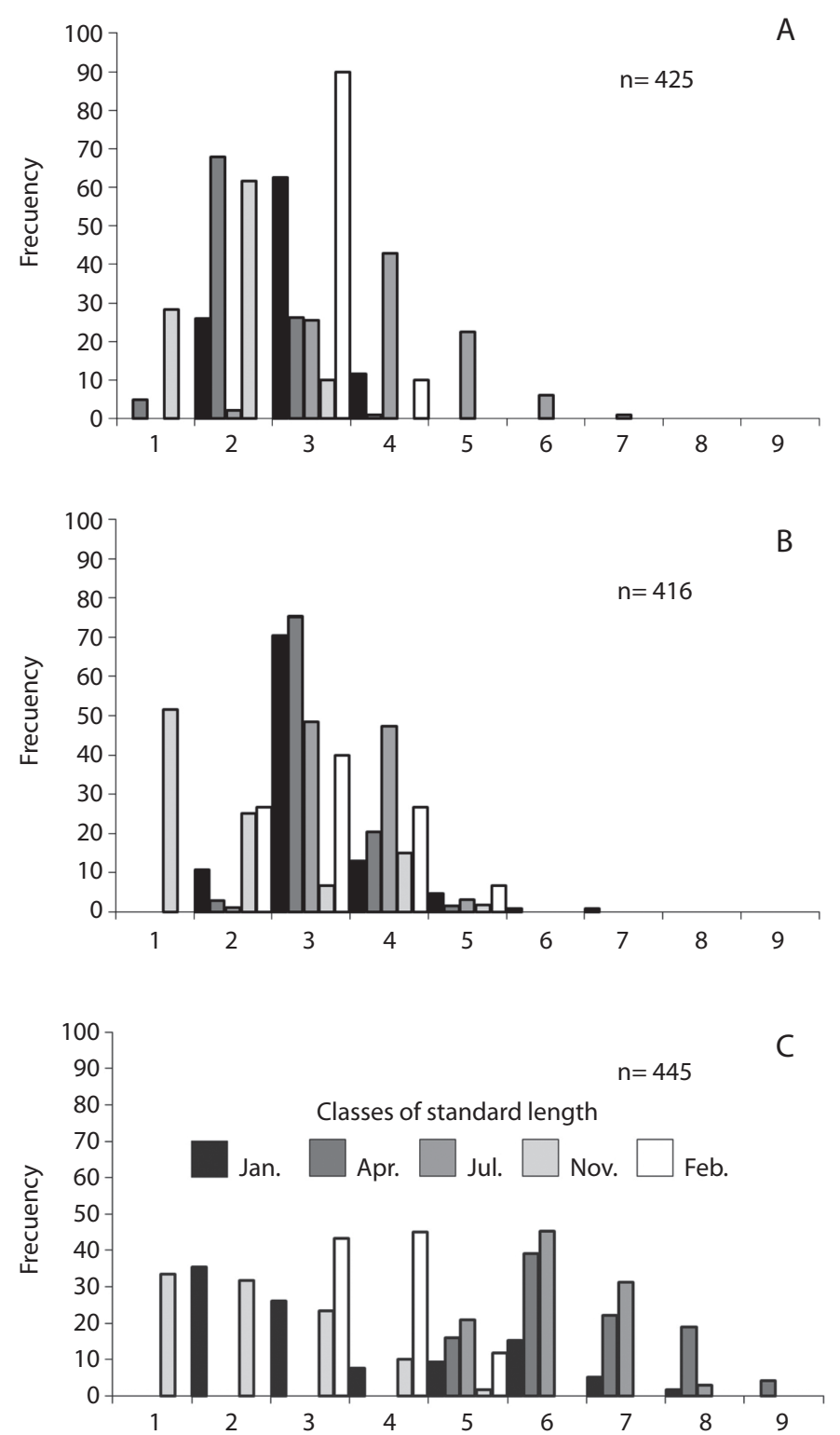

Fig. 3. Size class frequency distribution of Astyanax aeneus in three study sites of the Río Champotón: (A) Upper portion, (B) Middle portion, (C) Downstream.

Fig. 3. Distribución de clases de talla en Astyanax aeneus en tres sitios de estudio del Río Champotón: (A) Parte alta, (B) Parte media, (C) Río Abajo.

July. Males in stage 2 were present during all months and at all sites, except for the middle site in July and November (Figs. 6a and b). Mature females and males were found in the middle and downstream sites in April and July; females were most abundant at the downstream site in July (100\%), while males were more abundant in the middle site in July (95.65\%). Females with gonads in post-spawning stage were present at the downstream site in April, and showed low values in the middle site in July, while males with testes in post-spawning 

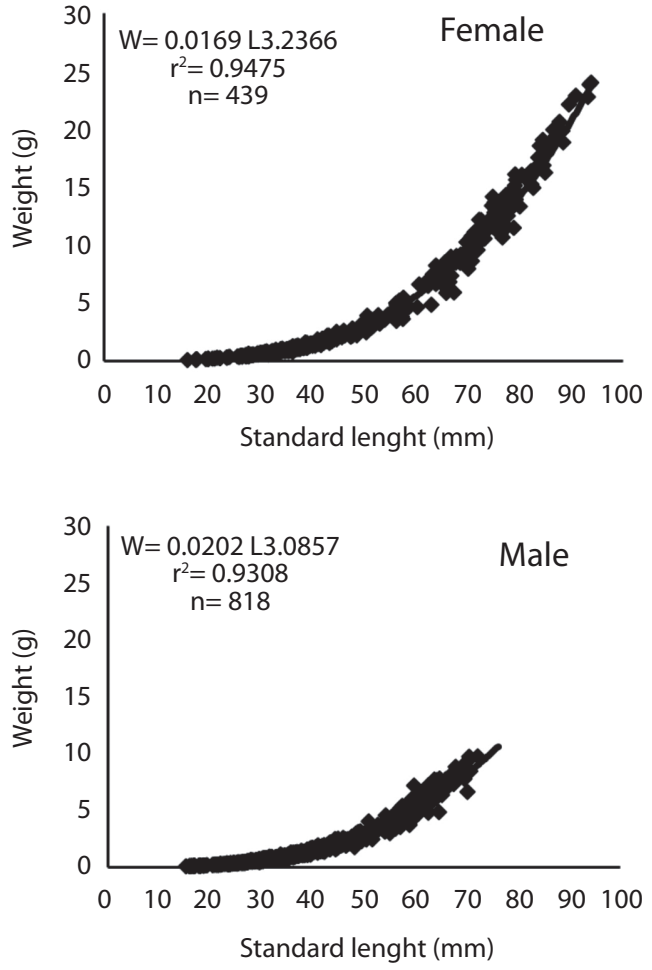

Fig. 4. Weight-length relationship of Astyanax aeneus in Champotón River. (A) Females; (B) Males.

Fig. 4. Relación peso-talla de Astyanax aeneus en el Río Champotón. (A) Hembras; (B) Machos.

stage were found only in the middle site in July (Figs. 6a and b). These data suggest that the reproductive period is from early spring to midsummer (from April to July).

Size at first maturity was $45.7 \mathrm{~mm}$ for females and $40.8 \mathrm{~mm}$ for males (Figs. $7 \mathrm{a}$ and b). AF ranged from 432 oocytes to 11890 oocytes in one female of $75.2 \mathrm{~mm}$ length. The lowest mean RF was at the middle site $(\mathrm{RF}=435.91 \pm 49.24$ oocytes/g), while the highest was recorded at the downstream site during July and April $(\mathrm{RF}=652.68 \pm 29.69$ and $394.8 \pm 29.11$ oocytes/g, respectively). RF was significantly correlated with Ls $(\mathrm{r}=0.58$, $\mathrm{p}<0.05)$ and $\mathrm{W}(\mathrm{r}=0.53, \mathrm{p}<0.05)$, while $\mathrm{AF}$ was significantly correlated with Ls $(\mathrm{r}=0.58$, $\mathrm{p}<0.05)$ and $\mathrm{W}(\mathrm{r}=0.53, \mathrm{p}<0.05)($ Figs. $8 \mathrm{a} \mathrm{y} \mathrm{b})$.

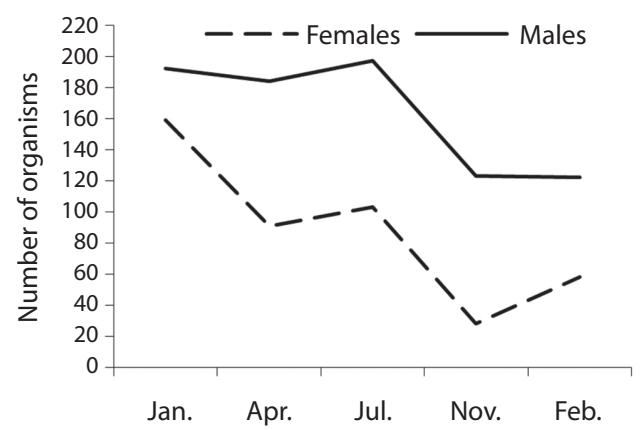

Fig. 5. Females and males during the study period.

Fig. 5. Hembras y machos durante el período de estudio.
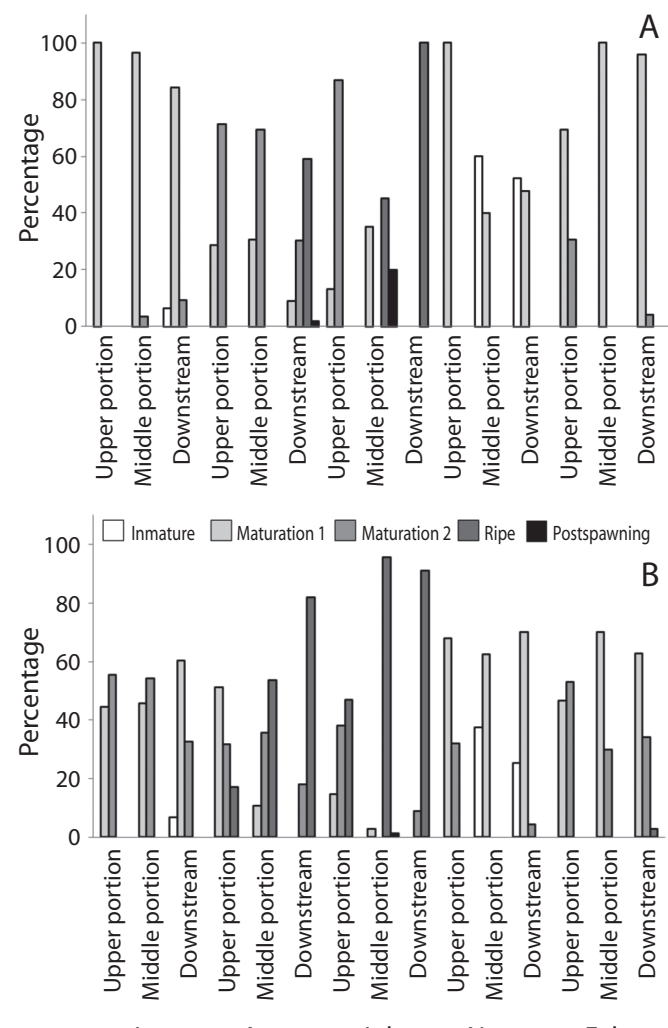

Jan. Apr. Jul. Nov. Feb.

Fig. 6. Gonadal maturation stages in percentages for both sexes: (A) Females; (B) Males.

Fig. 6. Etapas de maduración gonádica en porcentajes para ambos sexos: (A) Hembras; (B) Machos. 

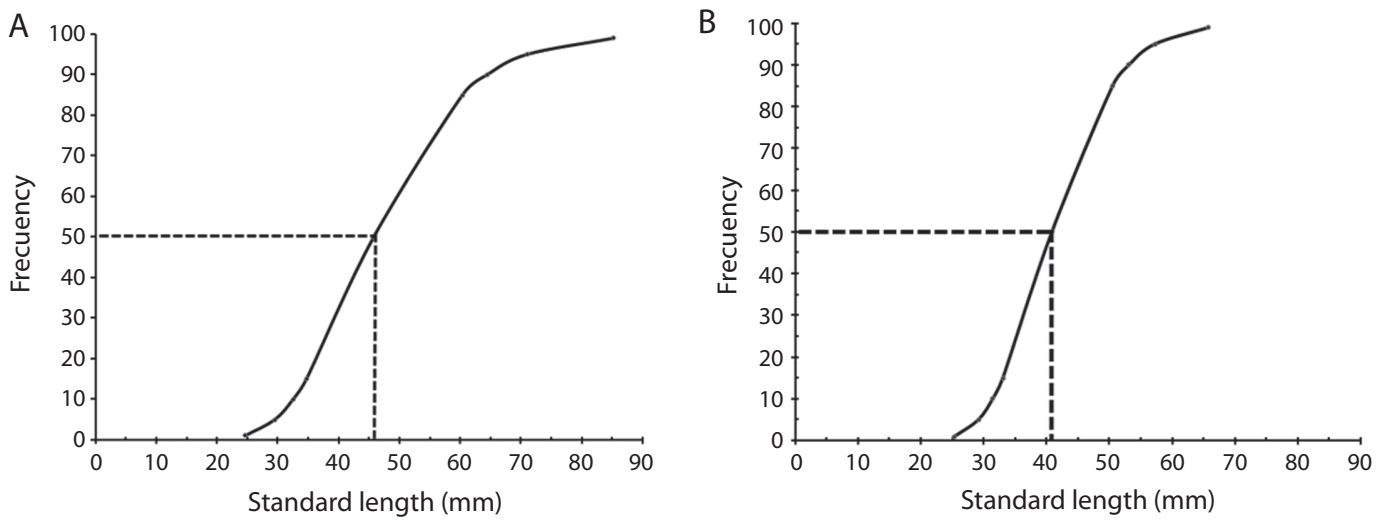

Fig. 7. Size at first sexual maturity of Astyanax aeneus in Champotón River. (A) Females and (B) Males.

Fig. 7. Talla de primera maduración en Astyanax aeneus en el Río Champotón. (A) Hembras; (B) Machos.
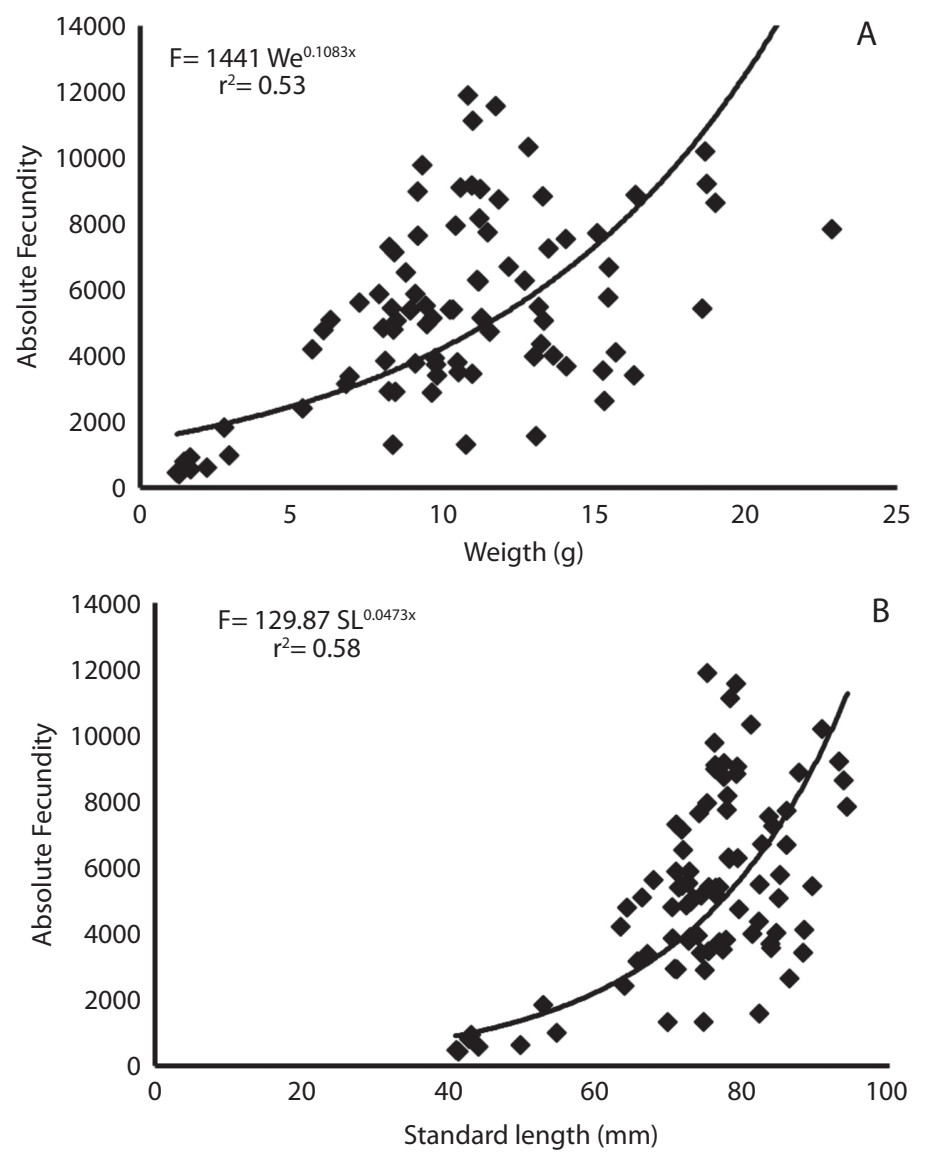

Fig. 8. Relationship between absolute fecundity and weight (A), and standard length (B) of Astyanax aeneus in the Río Champotón.

Fig. 8. Relación entre fecundidad absoluta y peso (A), y longitud patrón (B) de Astyanax aeneus en el Río Champotón. 
Somatic indices: Immature individuals were only found at the downstream site in January and November, and at the middle site in November with low GSI values; while HSI values of fishes from the middle site showed a peak in November $(5.49 \pm 0.52)$, and values of
$\mathrm{K}$ fluctuated from $1.69 \pm 0.05$ in the middle site to $2.02 \pm 0.04$ in the downstream site, both in November (Fig. 9a).

GSI values of females from the upper site ranged from $0.64 \pm 0.04$ in January to $2.93 \pm 0.48$ in July, while males showed lower values
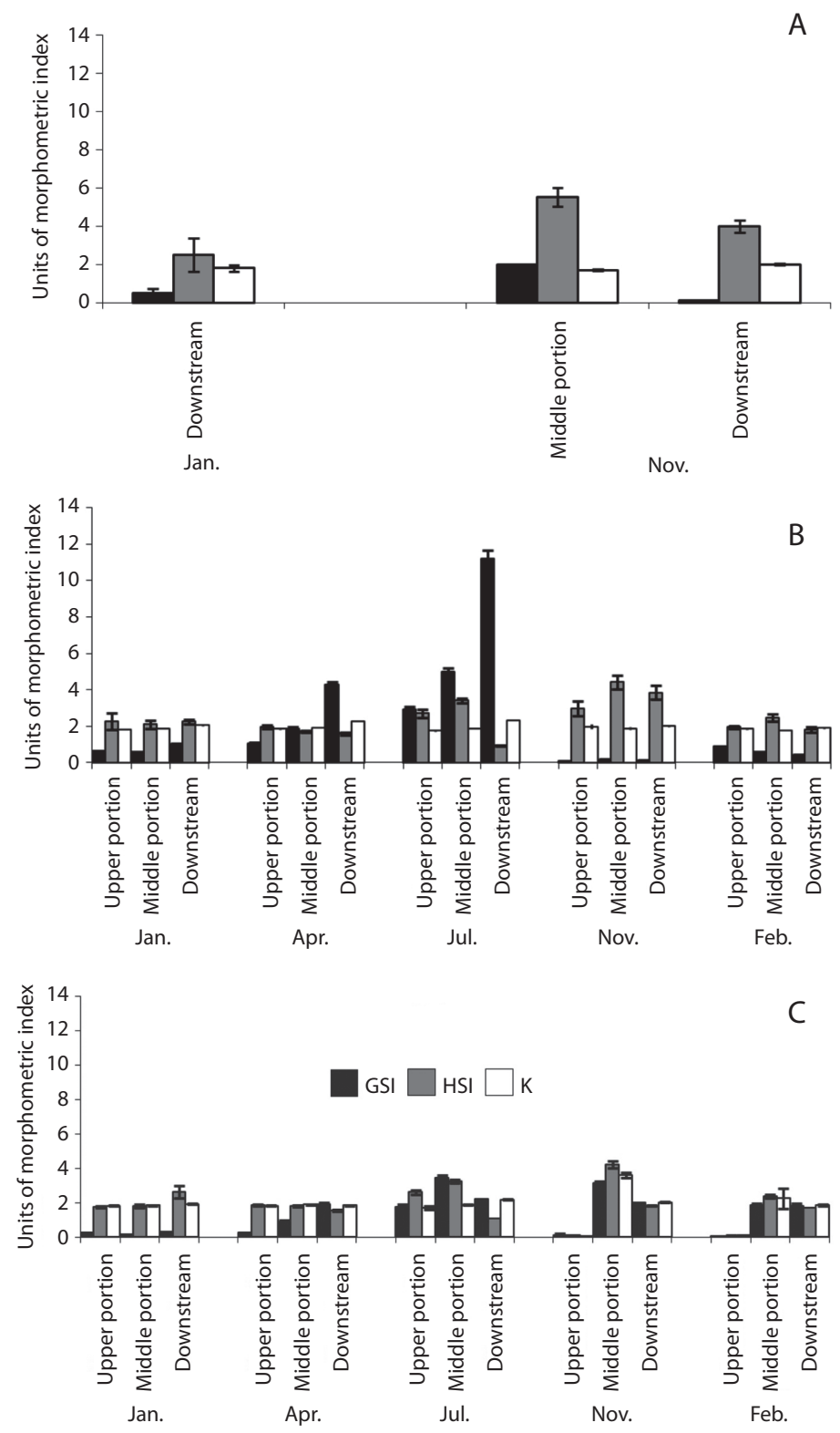

Fig. 9. Morphological parameters measured in Astyanax aeneus. GSI, gonadosomatic index; HSI, hepatosomatic index; K, condition factor. (a) Immature, (b) Females; (c) Males.

Fig. 9. Parámetros morfológicos medidos en Astyanax aeneus. GSI, índice gonadosomático; HSI, índice hepatosomático; K, factor de condición, (a) Inmaduros, (b) Hembras; (c) Machos. 
( $0.06 \pm 0.006$ in February to $1.77 \pm 0.15$ in July). In the middle site both females and males attained peak values in July (4.98 \pm 0.46 and $3.48 \pm 0.11$ respectively); both sexes had relatively low values in other months. Females from the downstream site had high GSI values in April (4.27 \pm 0.31$)$ and July (11.21 \pm 0.44$)$; males had lower values than females and attained their maximum value in April $(2.25 \pm 0.09)$ (Figs. 9b and c).

HSI scores in females from the upper site ranged from $1.94 \pm 0.08$ in February to $2.98 \pm 0.41$ in November, while males showed their minimum value in January $(1.75 \pm 0.06)$ and their maximum in November (3.24 \pm 0.13$)$. At the middle section, females had their minimum HSI value in April (1.72 \pm 0.05$)$ and males in January and April (1.82 \pm 0.08 both months); besides, females and males had higher values in July and November (females $3.4 \pm 0.14$ and $4.42 \pm 0.37$, respectively and males $3.25 \pm 0.08$ and $4.22 \pm 0.22$, respectively) (Figs. $9 \mathrm{~b}$ and c).

The lowest $\mathrm{K}$ values for both sexes from the upper site occurred in July $(1.73 \pm 0.03$ and $1.71 \pm 0.02$ in females and males, respectively), while the highest values were registered for females in January $(2.37 \pm 0.04)$ and for males in November $(2.02 \pm 0.02)$. At the middle site, the lowest $\mathrm{K}$ value was recorded in both females $(1.76 \pm 0.3)$ and males $(1.71 \pm 0.02)$ in February, and the highest for both sexes too ( $1.92 \pm 0.03$ females and $1.91 \pm 0.02$ males) in April. At the downstream site the lowest $\mathrm{K}$ value in females was in November and February (1.9 \pm 0.03 in both months), and the highest in July (2.33 \pm 0.02$)$, while in males, the lowest value occurred in April (1.86 \pm 0.03$)$ and February (1.87 \pm 0.06$)$, and the highest in July (2.20 \pm 0.03$)$ (Figs. 9b and c).

The correlation test between GSI and abiotic (temperature and precipitation) and biotic factors (HSI and $\mathrm{K}$ ) revealed no significant correlation except with regard to temperature, which displayed a significant correlation $(\mathrm{p}<0.0001)$.

Discriminant analysis revealed that standard length (Wilks' Lambda 0.344, p=0.0001), somatic indexes (K Wilks' Lambda 0.692, $\mathrm{p}=0.0001$ ), GSI (Wilks' Lambda 0.296, $\mathrm{p}=0.0001$ ); HSI (Wilks' Lambda 0.541, $\mathrm{p}=0.0001$ ), gonadal stages (Wilks' Lambda $0.402, \mathrm{p}=0.0001$ ); relative fecundity (Wilks' Lambda $0.671, \mathrm{p}=0.0001$ ), size classes (Wilks' Lambda 0.383, $\mathrm{p}=0.0001$ ), and sex (Wilks' Lambda $0.864, \mathrm{p}=0.0001$ ) were significant variables in the test model and allowed the formation of four groups in the first two components (Axes I and II: $87.22 \%$ of the variance explained) (Figs. 10a and b).

In the biplot of the discriminant analysis the upper and middle sites during November and February, and the downstream site during April and January were characterized by their high values for gonadal maturation stages and HSI. The downstream site in July, November and February was characterized by their high values for standard length, GSI, RF, a higher males / females ratio and the largest size classes. Additionally, this site was strongly correlated with greater water depth, river width, and dissolved oxygen. The upper and middle sections, were more closely correlated with a high temperature, precipitation, $\mathrm{BOD}_{5}, \mathrm{~K}$ and higher altitude in January and April, while the downstream site was correlated with the widest and deepest portion of the river (Figs. 10a and b).

\section{DISCUSSION}

The genus Astyanax is made up of smallsize species not exceeding $120 \mathrm{~mm}$ in maximum length (Miller et al. 2005). A. aeneus (size range $13-95 \mathrm{~mm}$ ) is a large-size species within this genus, like A. janeiroensis (25$115 \mathrm{~mm}$ ) (Mazzoni et al. 2005), as opposed to smaller species from the Paraguaçu River, Brazil, with standard length ranges $13-42 \mathrm{~mm}$ (Santos \& Novaes 2008) and intermediate size species such as $A$. aurocaudatus from the Cauca River, Colombia (14-74mm) (RománValencia \& Ruiz 2005).

Size-class frequency distribution of $A$. aeneus evidenced the differential use of spatial resources (sites) over time (study periods) in the longitudinal gradient of Champotón River. This may be the result of different 
(Axes F1 and F2: 87.21\%)
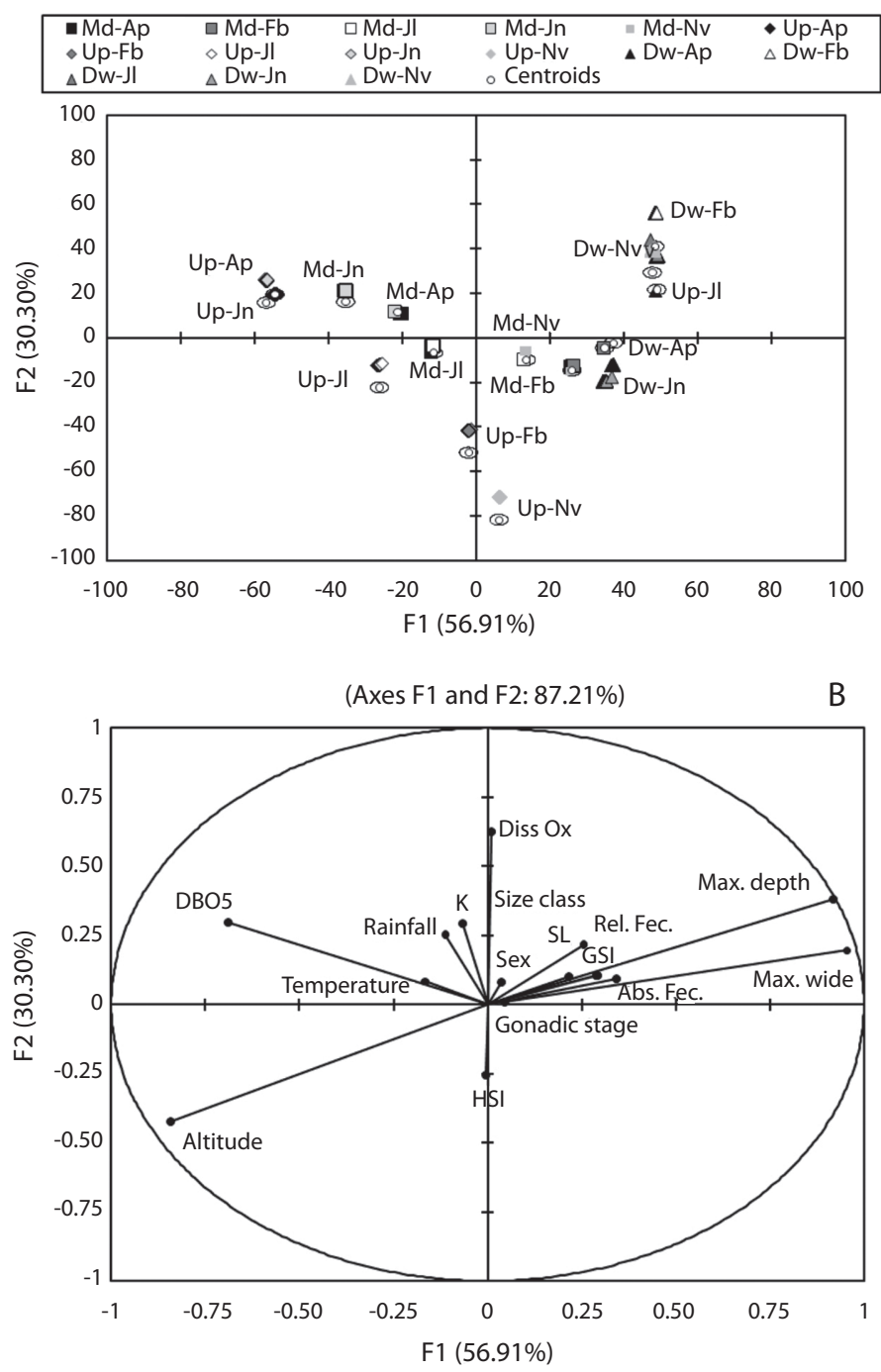

Fig. 10. Discriminant analysis biplot. (a) Dispersion of study sites in the biplot (the dot is the centroid of the study site). Letters after the study site (Up=Upper portion, $\mathrm{Md}=$ Middle portion, $\mathrm{DW}=$ Downstream) indicate the month: Jn, January; Fb, February; Ap, April; Jl, July; Nv, November; (b) Vectors of the environmental variables and parameters of reproduction, population structure and morphological indexes.

Fig. 10. Diagrama del análisis de discriminantes. (a) Dispersión de los sitios de estudio en el diagrama (el punto es el centroide de los sitios de estudio). Las letras después del sitio de estudio (Parte alta=Up, Parte media=Md, Río abajo=Dw) indican el mes: Jn, enero; Fb, febrero; Ap, abril; Jl, julio; Nv, noviembre. (b) Los vectores representan las variables ambientales, parámetros de reproducción, estructura de la población e índices morfológicos.

factors: period and location for reproduction, spatio-temporal variations in environmental conditions, and food availability. The largest classes $(>70 \mathrm{~mm})$, were found only at the downstream site, the deepest and widest site of the freshwater portion of the river, where floating cages are used for rearing fish that are feed with pellet food; this food is also available to wild fish. Smaller size classes had higher frequencies at the upper and shallow section of the 
river, with submerged and riparian vegetation which can be used by fish as a shelter or feeding area, while intermediate size classes had highest frequencies at the middle site, this is consistent with other characids findings (Sabino \& Castro 1990, Barreto \& Aranha 2005). In contrast Mazzoni et al. (2004), found that juvenile fish of $A$. janeiroensis were located downstream while adult organisms are located in the upper reaches of the Ubatiba river. Vitule et al. (2008) found that the size-class distribution of Deuterodon langei differs along the Paraná River basin: a higher number of largesize individuals were located at the upper and middle portion and juveniles occurred in higher abundance at the downstream.

A positive allometric growth was found in $A$. aeneus, meaning a greater increment in weight than in length (Orsi et al. 2002), perhaps related in turn to the reproductive period. Carvalho et al. (2009) report allometric growth in $A$. fasciatus, stating that the data may be skewed since most specimens were adults. A higher number of adult fish was also found in the present study.

Species with external fertilization and no parental care tend to have intermediate levels of fecundity, e.g. A. henseli (5 375 oocytes) (Dala-Corte \& Azevedo 2010), and low fecundity is commonly found in small-size species with traits that increase the probabilities of egg and larval survival such as internal fertilization and parental care, e.g. Bryconamericus iheringii (1 600 oocytes); Bryconamericus stramineus (1 100 oocytes) (Lampert et al. 2004, 2007). From this standpoint, A. aeneus has intermediate levels of fecundity.

Sex differences in body size and lengthweight relationship are the most frequent sexual dimorphism in fish (Nikolsky 1963). Females of $A$. aeneus were larger than males, this same trait was reported in other Characiformes (Agostinho \& Júlio-Júnior 1999) e.g. Astyanax bimaculatus, A. schubarti (Nomura 1975), A. eigenmanniorum (Barlá et al. 1988), A. fasciatus (Mora et al. 1997, Nomura 1975), A. scabripinnis (Veloso-Júnior et al. 2009), as opposed to A. aurocaudatus in which males are larger than females (Román-Valencia \& Ruiz 2005). Large females size is advantageous since fecundity is increased, while large males are at greater advantage during reproduction of producing potentially more, and larger, offspring (Nikolsky 1963). Sex ratio is an important trait in estimating reproductive biomass and total population fecundity and is also one of the factors determining the reproductive potential of a population (Marshall et al. 2006). An imbalance in the sex ratio, particularly in adults, is relatively common in fish and is related to sex differences in growth, mortality and/or the energy costs of reproduction and the formation of preponderantly male reproductive groups (Potts \& Wootton 1984, Marshall et al. 1998). In A. aeneus the sex ratio was skewed towards males. This same trait has been reported in A. bimaculatus vittatus (Gurgel \& Alves 2001); Characidium sp. n. (Mazzoni et al. 2002); Astyanax scabripinnis paranae (Louzada \& Orsi 2003); Hemibrycon sp. (Román-Valencia \& Botero 2006). Wootton (1998) found that some fish species with external fertilization had a higher male ratio during the reproductive cycle. However, most females have high levels of fecundity, which is advantageous since males are able to fertilize a larger number of oocytes, thus increasing the odds of perpetuation of the species.

The optimal first reproduction size depends on many factors, including the relative allocation of energy between gonadal and somatic growth (Mazzoni et al. 2005). In species of the genus Astyanax, size at first maturity varies from 41 to $78 \mathrm{~mm}$ (Veregue \& Orsi 2003, Mazzoni et al. 2005, Dala-Corte \& Azevedo 2010). A. aeneus reaches sexual maturity at $45.7 \mathrm{~mm}$ in females and $40.8 \mathrm{~mm}$ in males, smaller sizes than those in A. janeiroensis (55mm Mazzoni et al. 2005) and A. bimaculatus (69mm Agostinho et al. 1984); these species attain a similar size (Ls) in the course of their life cycle. Interpretation of the selection forces acting on the genus Astyanax suggests that early reproduction may be related to an adaptive behavior to offset the stochastic mortality imposed by unstable hydrological systems (Mazzoni \& Petito 1999), 
such as the Champotón River which is affected by the hurricane season (August and October). According to the National Weather Service, the frequency and intensity of hurricanes has risen in recent years: in 2007 five hurricanes were formed; in 2008 there were eight hurricanes, three of which were storms category four, while the most severe season was in 2010 when seven moderate and five strong hurricanes occurred (Servicio Meteorológico Nacional, 2007, 2008 \& 2010). Dala-Corte \& Azevedo (2010) point out that the reproductive tactic of small size at first maturity results in a rapid recruitment and, under favorable conditions, this may increases the number of juveniles produced thereby contributing to total population increase. Mazzoni \& Iglesias-Rios (2002) found variations in life history traits in Geophagus brasiliensis living in contrasting habitats (upper reaches and fluvial-lagunar conditions). The size at sexual maturity was smaller in the population living in the river (with unstable conditions), while population living in the lagoon was larger; this trait has been shown to be regulated by environmental conditions.

Environmental conditions permitting, extended reproductive periods are more common than short ones (Kramer 1978). However, tropical freshwater fishes (in particular cyprinids, characids and silurids, which comprise most of the tropical freshwater forms) are an interesting exception to this generalization since they have seasonal reproductive periods (Vazzoler \& Menezes 1992). Characidae species have their reproductive period between April and September (Vazzoler \& Menezes 1992, Lampert et al. 2004, 2007, Gonçalves et al. 2005). Reproduction season of $A$. aeneus is from April to July (spring and summer seasons), with a reproductive peak in July, when water levels rise. In tropical regions, various species take this event as a signal to carry out reproduction, as stated previously for $A$. fasciatus (Mora et al. 1997); A. bimaculatus (Braga 2001); A. aurocaudatus (Román-Valencia \& Ruiz 2005); A. scabrippinnis (Abilhoa 2007); A. henseli (Dala-Corte \& Azevedo 2010). Likewise, Lowe-McConnell (1987) found that in tropical regions spawning is stimulated by local rainfall or a rise in water levels. Lampert et al. $(2004,2007)$ found no correlation between reproductive traits and abiotic factors in Characidae from Rio Grande do Sul, Brazil in a subtropical region. However, the same authors recognize that a temperature increase may unleash the beginning of gonadal maturation. A. aeneus reveals that the beginning of the reproductive period takes place when there is an increase in temperature values as was detected by the positive correlation between GSI and water temperature, lending added support to the above-mentioned hypothesis.

A gradual increase in GSI values indicates the period of gonadal maturation while an abrupt fall signals the spawning season (HtunHan 1978). A better reproductive condition based on GSI of $A$. aeneus was during July. GSI variability was higher in females than in males, due to existing differences between ovaries and testes in terms of volume, mass, and energy demands for gamete production; this same trait was noted in A. fasciatus from Brazil (Carvalho et al. 2009).

HSI has been used to evidence the potential transfer of energy from the liver in order to maintain relevant biological events such as reproduction. During the reproductive period individuals allocate less effort to food procurement and consume reserves stored in the liver, eliciting a reduction in HSI values, particularly in females (Nikolsky 1963). In A. aeneus, higher HSI values were found during periods of reproductive inactivity. This is interpreted as an increase in the reserve materials stored in the liver for subsequent use in gamete production. In females low HSI values prior to and during reproduction may result from the transfer of energy materials stored in the liver toward gonadal maturation and the breeding event (Santos et al. 1996, Zimmerman 1997). A. henseli had higher HSI values before the breeding period and lower values at its reproductive peak, suggesting greater use of liver reserves for vitellogenesis and gonadal maturation (Dala-Corte \& Azevedo 2010). 
Condition factor, $\mathrm{K}$, reflects the physiological condition of fish and may be related, among other aspects, to food availability and individual size (Santos \& Novaes 2008). The latter authors state that values in two Astyanax species were higher during the wet season, which may be related to a greater supply of allochthonous food during this period. In the present study, the highest $\mathrm{K}$ value occurred in July (wet season) and at the downstream site for both sexes, and may be closely related to a greater supply of allochthonous food since at this site fish cultured in hanging cages are feed with food pellets, and native fish such as $A$. aeneus may ultimately have access to this food, that help them attain higher $\mathrm{K}$ values.

Mazzoni et al. (2002) state that the reproductive strategy of Characidium sp. from the Ubatiba River suggests high reproductive effort, which is reflected in: (i) early onset of sexual maturity, (ii) high GSI, (iii) an extended reproductive period, and (iv) high fecundity (1 342 to 5535 oocytes). The latter authors point out that, according to life-history theory, the trade-offs between these traits and optimal reproductive life ensure species maintenance.

Winemiller \& Rose (1992) describe three different life-history strategies: opportunistic, which is associated with early maturity, small oocytes, small clutches and continuous spawning; periodic, found in large fish with synchronous reproduction, high fecundity and no parental care which breed at the beginning of the wet season; and equilibrium, which includes large fish with parental care and an intermediate number of large oocytes. Winemiller (1989) and Winemiller \& Rose (1992) predict that periodic and equilibrium strategies may predominate in upper reaches of rivers while opportunistic strategies may dominate in the lower reaches. Our results show that $A$. aeneus (living from the upper to the middle reaches of the Champotón River) exhibits a periodic strategy.

Local short-distance fish movements may be a response to habitat gradients, abiotic conditions (salinity, current velocity, DO) or to the availability of resources (food).
Ontogeny-related local migrations are an important life-history trait of inland water, estuarine and marine fish worldwide (Winemiller \& Jepsen 1998). Our results indicate that A. aeneus exhibits local ontogenetic migration as shown by the presence of small-size individuals in the upper reaches, primarily after the hurricane season (when the river overflows its banks in November) and the predominance of larger-size adults in the middle reaches and downstream, particularly during the reproductive period (April and July). Winemiller \& Jepsen (1998) point out that floods allow fish to come into contact with a greater variety and abundance of allochthonous food resources, which may be advantageous for growing fish. Furthermore, $A$. aeneus in the Champotón River exhibits early sexual maturity $(45.7 \mathrm{~mm}$ in females and $40.8 \mathrm{~mm}$ in males), a short reproductive period with high GSI values, and high fecundity (432 to 11890 oocytes), a tradeoff for the short reproductive period.

The overall reproductive strategy of $A$. aeneus suggests that most of the energy is allocated towards reproduction in order to compensate for the unpredictable hydrological conditions imposed by the Champotón River (particularly during the hurricane season). This strategy has enabled $A$. aeneus not only to complete its life cycle, but also to be one of the species with the widest distribution, highest abundance and frequency of occurrence in the Champotón River fish assemblage (LópezLópez et al. 2009), making clear the success of the strategy of $A$. aeneus in adapting to the river conditions.

\section{ACKNOWLEDGMENTS}

The study was supported by the National Science and Technology Council (CONACyT-México) and the government of the state Campeche (Project: 31173) and the Secretariat of Research and Posgraduate Studies (SIP) of the National Polytechnic Institute (IPN-México). 


\section{RESUMEN}

El Río Champotón es un área de desconocimiento científico dentro del hotspot de Mesoamérica en el sureste de México. Las características reproductivas y la estructura de la población de Astyanax aeneus fueron analizadas a lo largo de un gradiente ambiental en la porción dulceacuícola del río. Se estudiaron tres sitios: en la parte alta del río San Juan Carpizo, en la porción media San Antonio del Río y río abajo en Ulumal, en cinco períodos entre 2007 y 2008. Se registraron diversos factores ambientales en cada sitio de estudio. Los ejemplares de A. aeneus se recolectaron con redes de arrastre de 5 y $10 \mathrm{~m}$ de largo por $5 \mathrm{~m}$ de profundidad $(0.03 \mathrm{~m}$ malla) y atarraya (con luz de malla de $0.05 \mathrm{~m}$ ). Las redes fueron lanzadas durante 1 hora en cada sitio. En cada visita se recolectaron un promedio de 80 especímenes en cada sitio de estudio que se preservaron en formaldehído al $10 \%$ para su posterior análisis. Para cada sitio de estudio se analizó la estructura de la población por talla, con base en las frecuencias relativas de las clases de longitud estándar. Se determinó la relación peso-talla, se identificaron las etapas del desarrollo gonadal, la época reproductiva, el tamaño de primera madurez sexual, la fecundidad absoluta y relativa, la proporción de sexos y los índices somáticos (gonadosomático, hepatosomático y el factor de condición de Fulton). Se obtuvieron siete clases de talla en la parte alta y media del río y nueve río abajo, con un patrón de distribución estacional y espacial en las frecuencias de clase de tallas. La talla de primera madurez fue de $45.7 \mathrm{~mm}$ en hembras y $40.8 \mathrm{~mm}$ en machos. La máxima fecundidad absoluta se registró río abajo y se correlacionó positivamente con el peso corporal y la longitud estándar. La proporción de sexos (1.8:1 machos: hembras) difiere significativamente de los valores esperados (1:1). Los resultados del índice gonadosomático (IGS) indican que el período reproductivo en el Río Champotón es en julio, durante la temporada húmeda y cálida. El índice hepatosomático se correlacionó negativamente con el IGS, evidenciando la transferencia de energía desde el hígado hacia la producción de gametos. Esta estrategia permitió que $A$. aeneus mantuviera una condición robusta durante el periodo de estudio con pequeños cambios en el factor de condición. Nuestros resultados indican que $A$. aeneus en el río Champotón, a diferencia de otras especies del mismo género y de la misma talla en ríos de Sudamérica, presenta una maduración sexual precoz, una temporada reproductiva corta con elevados valores del IGS, y una elevada fecundidad, lo que compensa la temporada de reproducción corta. También se percibe una tendencia a la segregación espacial y temporal: los reproductores se congregan aguas abajo y los juveniles prefieren las partes más altas. Este patrón permite a $A$. aeneus tener éxito en un río con una alta frecuencia de huracanes.

Palabras clave: Astyanax aeneus, primera maduración, fecundidad absoluta, historia de vida, huracanes, gradiente ambiental.

\section{REFERENCES}

Adebisi, A.A. 1987. The relationships between fecundities, gonadosomatic indices and eggs sizes of some fishes of Ogun River, Nigeria. Arch. Hydrobiol. Stuttgart 111: 151-156.

Agostinho, C.A., S. Molinari, A.A. Agostinho \& J. Verani. 1984. Ciclo reprodutivo e primeira maturação sexual de fêmeas do lambari Astyanax bimaculatus (L.) (Osteichthyes-Characidae) do rio Ivaí. Estado do Paraná. Rev. Braz. Biol. 44: 31-36.

Agostinho, A.A. \& H.F. Julio-Junior. 1999. Peixes da bacia do alto rio Paraná, p. 374-400. In R.H. LoweMcConnell (ed). Estudos ecológicos de comunidades de peixes tropicais. Universidade de São Paulo, São Paulo, Brasil.

Abilhoa, V. 2007. Aspectos da história natural de Astyanax scabripinnis Jenyns (Teleostei, Characidae) em um riacho de floresta com araucária no sul do Brasil. Rev. Braz. Zool. 24: 997-1005.

American Public Health Association. 2005. Standard methods: for the examination of water and wastewater. American Public Health Association, Baltimore, Maryland, USA.

Barlá, M.J., L.R. Freyre, L.M. Giraudo, M. Gutiérrez \& E.D. Sendra. 1988. Age and growth of Astyanax eigenmanniorum (Cope) (Pisces, Characiformes) from San Roque lake, Argentina. Stud. Neotrop. Fauna Environ. 23: 177-188.

Barreto, A.P. \& J.M.R. Aranha. 2005. Assembléia de peixes de um riacho da Floresta Atlântica: composição e distribuição espacial (Guaraqueçaba, Paraná, Brasil). Acta Sci. Biol. Sci. 27: 153-160.

Braga, F.M.S. 2001. Reprodução de peixes (Osteichthyes) em afluentes do reservatório de Volta Grande, Rio Grande, sudeste do Brasil. Iheringia, Ser. Zool. 91: 67-74.

Carvalho, P.A., A.L. Paschoalini, G.B. Santos, E. Rizzo \& N. Bazzoli. 2009. Reproductive biology of Astyanax fasciatus (Pisces: Characiformes) in a reservoir in southeastern Brazil. J. Appl. Ichthyol. 25: 306-313.

Dala-Corte, R. \& M.A. Azevedo. 2010. Biologia reprodutiva de Astyanax henseli (Teleostei, Characidae) do curso superior do rio dos Sinos, RS, Brasil. Iheríngia Ser Zool. 100: 259-266.

Environmental Protection Agency (EPA). 2011. Statistical Analysis for Biological Methods. (Downloaded: 23 March 2011, http://www.epa.gov/nerleerd/stat2. htm.).

Gertum, B.F., S. Carvalho \& S.M. Hartz. 2008. Life-history of the South American darter, Characidium pterosticum (Crenuchidae): evidence for small scale spatial variation in a piedmont stream. Neotrop. Ichthyol. 6: 591-598. 
Gomiero, L.M., L. Garuana \& F.M.S. Braga. 2008. Reproduction of Oligosarcus hepsetus (Cuvier, 1829) (Characiformes) in the Serrado Mar State Park, São Paulo, Brazil. Braz. J. Biol. 68: 187-192.

Gonçalves, T.K., M.A. Azevedo, L.R. Malabarba \& C.B. Fialho. 2005. Reproductive biology and development of sexually dimorphic structures in Aphyocharax anisitsi (Ostariophysi: Characidae). Neotrop. Ichthyol. 3: 433-438.

Gurgel, B.H.C. \& M.V. Alves. 2001. Estrutura populacional de Astyanax bimaculatus vittatus (Castelnau, 1855) (Characidae, Tetragonopterinae) do Rio CearáMirim, Poço Branco, RN. Rev. Ceres 48: 159-168.

Htun-Han, M. 1978. The reproductive biology of the dab Limanda limanda (L) in the North Sea: Gonadosomatic index, Hepatosomatic index and Condition factor. J. Fish Biol. 13: 369-378.

Jones, R.E., R.J. Petrell \& D. Pauly. 1999. Using modified length-weight relationships to assess the condition of fish. Aquacult. Eng. 20: 261-276.

Kinnison, M.T., M.J. Unwin, A.P. Hendry \& T.P. Quinn. 2001. Migratory costs and the evolution of egg size and number in introduced and indigenous Salmon populations. Evolution 55: 1656-1667.

Kramer, L.D. 1978. Reproductive seasonality in the fishes of a tropical stream. Ecology 59: 976-985.

Lampert, R.V., M.A. Azevedo \& C.B. Fialho. 2004. Reproductive biology of Bryconamericus iheringii (Ostariophysi: Characidae) from rio Vacacaí, RS, Brazil Neotrop. Ichthyol. 2: 209-215.

Lampert, V.R., M.A. Azevedo \& C.B. Fialho. 2007. Reproductive Biology of Bryconamericus stramineus Eigenmann, 1908 (Ostariophysi: Characidae) from rio Ibicuí, RS, Brazil. Braz. Arch. Biol. Technol. 50: 995-1004.

Lourenço, S.L., A.L. Mateus \& G.N. Machado. 2008. Sincronia na reprodução de Moenkhausia sanctaefilomenae (Steindachner) (Characiformes: Characidae) na planície de inundação do rio Cuiabá, Pantanal Mato-grossense, Brasil. Rev. Braz. Zool. 25: 20-27.

López-López, E., J.E. Sedeño-Díaz, F. López-Romero \& P. Trujillo-Jiménez. 2009. Spatial and seasonal distribution patterns of fish assemblages in the Río Champotón, southeastern México. Rev. Fish Biol. Fisher. 21: 127-142.

Louzada, V.A.M. \& M.L. Orsi. 2003. Biologia reprodutiva de Astyanax scabripinnis paranae (Eigenmann) (Osteichthyes, Characidae), do ribeirão das marrecas, bacia do rio Tibagi, Paraná. Rev. Braz. Zool. 20: 97-105.

Lowe-McConnell, R. 1987. Ecological studies in tropical fish communities. Cambridge University, London, United Kingdom.
Magalhâes, M.F., I.J. Schlosser \& M.J. Collares-Pereida. 2003. The role of life history in the relationship between population dynamics and environmental variability in two Mediterranean stream fishes. J. Fish Biol. 63: 300-317.

Marshall, C.T., O.S. Kjesbu, N.A. Yaragina, P. Solemdal \& O. Ulltang. 1998. Is spawner biomass a sensitive measure of the reproductive and recruitment potential of northeast Arctic cod? Can. J. Fish. Aquat. Sci. 55: 1766-1783.

Marshall, C.T., C. L. Needle, A. Thorsen, O.S. Kjesbu \& N.A. Yaragina. 2006. Systematic bias in estimates of reproductive potential of an Atlantic cod (Gadus morhua) stock: implications for stock-recruit theory and management. Can. J. Fish. Aquat. Sci. 63: 980-994.

Mazzoni, R., E.P. Caramaschi \& N. Fenerich-Verani. 2002. Reproductive biology of Characidiinae (Osteichthyes, Characidae) from the Ubatiba river, Maricá-RJ. Braz. J. Biol. 62: 487-494.

Mazzoni, R. \& R. Iglesias-Rios. 2002. Environmentally related life history variations in Geophagus brasiliensis. J. Fish Biol. 61: 1606-1618

Mazzoni, R. \& R. Iglesias-Rios. 2007. Patterns of investment of the reproductive strategy of two streamdwelling Characidae. Braz. J. Biol. 67: 695-699.

Mazzoni, R., R.S. Mendonça \& E.P. Caramaschi. 2005. Reproductive biology of Astyanax janeiroensis (Osteichthyes, Characidae) from the Ubatiba River, Maricá, RJ, Brazil. Braz. J. Biol. 65: 643-649.

Mazzoni, R. \& J.T. Petito. 1999. Reproductive biology of a Tetragonopterinae (Osteichthyes, Characidae) of the Ubatiba fluvial system, Maricá-RJ. Braz. Arch. Biol. Tech. 42: 455-461.

Mazzoni, R., S.A. Schubart \& R. Iglesias-Rios. 2004. Longitudinal segregation of Astyanax janeiroensis in Rio Ubatiba: a Neotropical stream of south-east Brazil. Ecol. Freshw. Fish. 13: 231-234.

Miller, R.R., W.L. Minckley \& S.M. Norris. 2005. Freshwater fishes of Mexico. University of Michigan, Museum of Zoology, Chicago, USA.

Mora, J.M., P. Cabrera \& B.W. Alvarado. 1997. Crecimiento y maduración sexual de Astyanax fasciatus (Pisces: Characidae) en el embalse Arenal, Guanacaste, Costa Rica. Rev. Biol. Trop. 45: 855-859.

Myers, N., A. Russell, C.G. Mittermeier, G.A.B. Mittermeier da Fonseca \& J. Kent. 2000. Biodiversity hotspots for conservation priorities. Nature 403: 853-858.

Nikolsky, G.V. 1963. The ecology of fishes. Academic, London, United Kingdom.

Nomura, H. 1975. Comparação da idade e do crescimento de três espécies de peixes do gênero Astyanax Baird \& Girard, 1854 (Osteichthyes, Characidae) do rio Mogi Guaçu, SP. Rev. Bras. Biol. 35: 531-547. 
Orsi, M.L., O.A. Shibatta \& A.T. Silva-Souza. 2002. Caracterização biológica de populações de peixes do rio Tibagi, localidade de Sertanópolis, p. 425-432. In M.E. Medri, O.A. Shibatta, E. Bianchini \& J.A. Pimienta. (eds.). A Bacia do Rio Tibagi. Universidade Estadual de Londrina, Paraná, Brasil.

Potts, G.W. \& R.J. Wootton. 1984. Fish reproduction strategies and tactics. Academic, London, United Kingdom.

Román-Valencia, C. \& A. Botero. 2006. Trophic and reproductive ecology of a species of Hemibrycon (Pisces: Characidae) in Tinajas creek, Quindío River drainage, upper Cauca basin, Colombia. Rev. Mus. Argent. Cienc. Nat. 8: 1-8.

Román-Valencia, C. \& R. Ruiz. 2005. Diet and reproduction aspects of Astyanax aurocaudatus (Teleostei:Characidae) from the upper part of the Cauca River, Colombia. Dahlia. Rev. Assoc. Colm. Ictiol. 8: 9-17.

Ryan, J.M. \& A.S. Rand. 1993. Species recognition and sexual selection as a unitary problem in animal communication. Evolution 47: 647-657.

Sabino, J. \& R.C. Castro. 1990. Alimentação, período de atividade e distribuição espacial dos peixes de um riacho de floresta atlântica (sudeste do Brasil). Rev. Bras. Biol. 50: 23-36.

Samat, A., M.N. Shukor, A.G. Mazlan, A. Arshad \& M.Y. Fatimah. 2008. Length-weight relationship and condition factor of Pterygoplichthys pardalis (Pisces: Loricariidae) in Malaysia Peninsula. Res. J. Fisher. Hydrobiol. 3: 48-53.

Santos, R.S., S.J. Hawkinis \& R.D. Nash. 1996. Reproductive phenology of the Azorean rock pool blenny a fish alternative mating tactics. J. Fish Biol. 48: 842-858.

Santos, A.C.A. \& J.L.C. Novaes. 2008. Population structure of two Astyanax Baird \& Girard, 1854 (Teleostei, Characidae) species from Upper Paraguaçu River. Braz. Arch. Biol. Technol. 51: 105-112.

Servicio Meteorológico Nacional. 2007. Resumen de la temporada de ciclones tropicales 2008. (Downloaded: 15 Novembrer 2010, http://smn.cna.gob.mx/ciclones/ tempo2007/RTCT-2007.pdf.).

Servicio Meteorológico Nacional. 2008. Resumen de la temporada de ciclones tropicales 2008. (Downloaded: 15 Novembrer 2010, http://smn.cna.gob.mx/ciclones/ tempo2008/RTCT-2008.pdf.).

Servicio Meteorológico Nacional. 2010. Resumen de la temporada de ciclones tropicales 2010. (Downloaded: 15 Novembrer 2010, http://smn.cna.gob.mx/ciclones/ tempo2010/RTCT-2010.pdf.).
Stearns, S.C. 1994. The evolution of life histories. Oxford University, Oxford, United Kingdom.

Vazzoler, A.E.A.M. 1996. Biologia da reprodução de peixes teleósteos: Teoria e prática. EDUEM/SBI, São Paulo, Brasil.

Vazzoler, A.E.A.M. \& N.A. Menezes. 1992. Sintese dos conhecimentos sobre o comportamento reprodutivo dos Characiformes da América do Sul (Teleostei, Ostariophysi). Rev. Bras. Biol. 52: 627-640.

Veloso-Júnior, V.C., R.J. Guimarães-Cruz, M.D.M. Barros, R.S.L. Barata \& J.E. Santos. 2009. Reproduction of the lambari Astyanax scabripinnis (Jenyns, 1842) (Pisces:Characidae) in a small stream in Southeastern Brazil. J. Appl. Ichthyol. 25: 314-320.

Veregue, A.M. \& M.L. Orsi. 2003. Biologia reprodutiva de Astyanax scabripinnis paranae (Eigenmann) (Osteichthyes: Characidae) do ribeirao das Marrecas, bacia do rio Tibagi, Paraná. Rev. Bras. Zool. 20: 97-105.

Vitule, J.R.S., F.F. Gazola-Silva \& J.M.R. Aranha. 2007. Desenvolvimento gonadal de Deuterodon langei Travassos (Teleostei: Characidae). Acta Biol. Parana. 36: 113-119.

Vitule, J.R.S., M.B. Rennó \& J.M.A. Rocha. 2008. Population structure and reproduction of Deuterodon langei Travassos, 1957 (Teleostei, Characidae) in a Neotropical stream basin from the Atlantic Forest, Southern Brazil. Braz. Arch. Biol. Technol. 51: 1187-1198.

Winemiller, K.O. 1989. Patterns of variation in life history among South American fishes in seasonal environments. Oecologia 81: 225-241.

Winemiller, K.O. \& D.B. Jepsen. 1998. Effects of seasonality and fish movement on tropical river food webs. J. Fish Biol. 53: 267-296.

Winemiller, K.O. \& K.A. Rose. 1992. Patterns of life history diversification in North American fishes: implications for population regulation. Can. J. Fisher. Aquat. Sci. 49: 2196-2218.

Wootton, J.R. 1998. Ecology of teleost fishes. Kluwer Academic, New York, USA.

Wunder, B.A. 1992. Morphophysiological indicators of the energy state of small mammals, p. 83-104. In T.E. Tomasi \& T.H. Horton (eds.). Mammalian energetics: Interdisciplinary reviews of metabolism and reproduction. Cornell University, New York, USA.

XLSTAT. 2010. Statistical software for MS Excel. Ver. 2010-2.01.

Zimmerman, M. 1997. Maturity and fecundity of arrow tooth flounder, Atheresthes stomias, from the Gulf of Alaska. Fish. Bull. 95: 598-611. 